\title{
Estrogen Receptor Modulators in Viral Infections Such as SARS-CoV-2: Therapeutic Consequences
}

\author{
Nikita Abramenko 1,2 ${ }^{\mathbb{D}}$, Fréderic Vellieux ${ }^{1} \mathbb{D}$, Petra Tesařová ${ }^{3}$, Zdeněk Kejík ${ }^{1,2} \mathbb{D}^{\mathbb{D}}$, Robert Kaplánek ${ }^{1,2} \mathbb{D}^{\mathbb{D}}$, \\ Lukáš Lacina 1,4,5 (D), Barbora Dvořánková ${ }^{1,4}$, Daniel Rösel ${ }^{6}\left(\mathbb{D}\right.$, Jan Brábek ${ }^{6}$, Adam Tesař ${ }^{7}$, Milan Jakubek ${ }^{1,2}{ }^{(\mathbb{D})}$ \\ and Karel Smetana, Jr. $1,4, *$ (D)
}

check for updates

Citation: Abramenko, N.; Vellieux, F.; Tesařová, P.; Kejík, Z.; Kaplánek, R.; Lacina, L.; Dvořánková, B.; Rösel, D.; Brábek, J.; Tesař, A.; et al. Estrogen Receptor Modulators in Viral Infections Such as SARS-CoV-2: Therapeutic Consequences. Int. J. Mol Sci. 2021, 22, 6551. https://doi.org/ $10.3390 /$ ijms 22126551

Academic Editors: Francesco Caruso and Miriam Rossi

Received: 17 May 2021

Accepted: 16 June 2021

Published: 18 June 2021

Publisher's Note: MDPI stays neutral with regard to jurisdictional claims in published maps and institutional affiliations.

Copyright: (c) 2021 by the authors. Licensee MDPI, Basel, Switzerland This article is an open access article distributed under the terms and conditions of the Creative Commons Attribution (CC BY) license (https:// creativecommons.org/licenses/by/ $4.0 /)$
1 BIOCEV, First Faculty of Medicine, Charles University, 25250 Vestec, Czech Republic; nikita.abramenko@lf1.cuni.cz (N.A.); frederic.vellieux@lf1.cuni.cz (F.V.); zdenek.kejik@lf1.cuni.cz (Z.K.); robert.kaplanek@lf1.cuni.cz (R.K.); lukas.lacina@lf1.cuni.cz (L.L.); barbora.dvorankova@lf1.cuni.cz (B.D.); milan.jakubek@lf1.cuni.cz (M.J.)

2 Department of Paediatrics and Inherited Metabolic Disorders, First Faculty of Medicine, Charles University and General University Hospital, 12000 Prague, Czech Republic

3 Department of Oncology, First Faculty of Medicine, Charles University and General University Hospital, 12000 Prague, Czech Republic; petra.tesarova@vfn.cz

4 Institute of Anatomy, First Faculty of Medicine, Charles University, 12000 Prague, Czech Republic

5 Department of Dermatovenereology, First Faculty of Medicine, Charles University and General University Hospital, 12000 Prague, Czech Republic

6 BIOCEV, Faculty of Sciences, Charles University, 25250 Vestec, Czech Republic; daniel.rosel@natur.cuni.cz (D.R.); jan.brabek@natur.cuni.cz (J.B.)

7 Department of Neurology, First Faculty of Medicine, Charles University, 12000 Prague, Czech Republic; adam.tesar@vfn.cz

* Correspondence: karel.smetana@lf1.cuni.cz; Tel.: +420-0224-965-873

\begin{abstract}
COVID-19 is a pandemic respiratory disease caused by the SARS-CoV -2 coronavirus. The worldwide epidemiologic data showed higher mortality in males compared to females, suggesting a hypothesis about the protective effect of estrogens against severe disease progression with the ultimate end being patient's death. This article summarizes the current knowledge regarding the potential effect of estrogens and other modulators of estrogen receptors on COVID-19. While estrogen receptor activation shows complex effects on the patient's organism, such as an influence on the cardiovascular/pulmonary/immune system which includes lower production of cytokines responsible for the cytokine storm, the receptor-independent effects directly inhibits viral replication. Furthermore, it inhibits the interaction of IL-6 with its receptor complex. Interestingly, in addition to natural hormones, phytestrogens and even synthetic molecules are able to interact with the estrogen receptor and exhibit some anti-COVID-19 activity. From this point of view, estrogen receptor modulators have the potential to be included in the anti-COVID-19 therapeutic arsenal.
\end{abstract}

Keywords: COVID-19; SARS-CoV-2; estrogen; estrogen receptor; viral replication; IL-6; cytokine storm

\section{Introduction}

COVID-19 is a severe respiratory infection that possesses a pandemic character caused by the SARS-CoV-2 coronavirus, which is a virus similar to the SARS and MERS viruses. Published global epidemiologic data show that while the incidence of infection is only negligibly sex-dependent with some protective role of estrogens in premenopausal women, males die more frequently than females [1,2]. Data from the Ministry of Health of the Czech Republic released up to mid-February 2021 does not contradict these observations (Figures 1 and 2). Experimental data obtained from ovariectomized mice showed more severe courses of SARS-CoV or MERS infections than in control animals [3], which also supports the hypothesis that estrogens possess a certain protective effect against viral infection in females because of their anti-inflammatory and immunomodulatory effect [4]. 
However, data concerning the role of estrogens are equivocal because there are no significant differences in mortality observed between premenopausal and postmenopausal Chinese women [5]. This can be due to the high dietary intake of isoflavonoids in Eastern Asia.

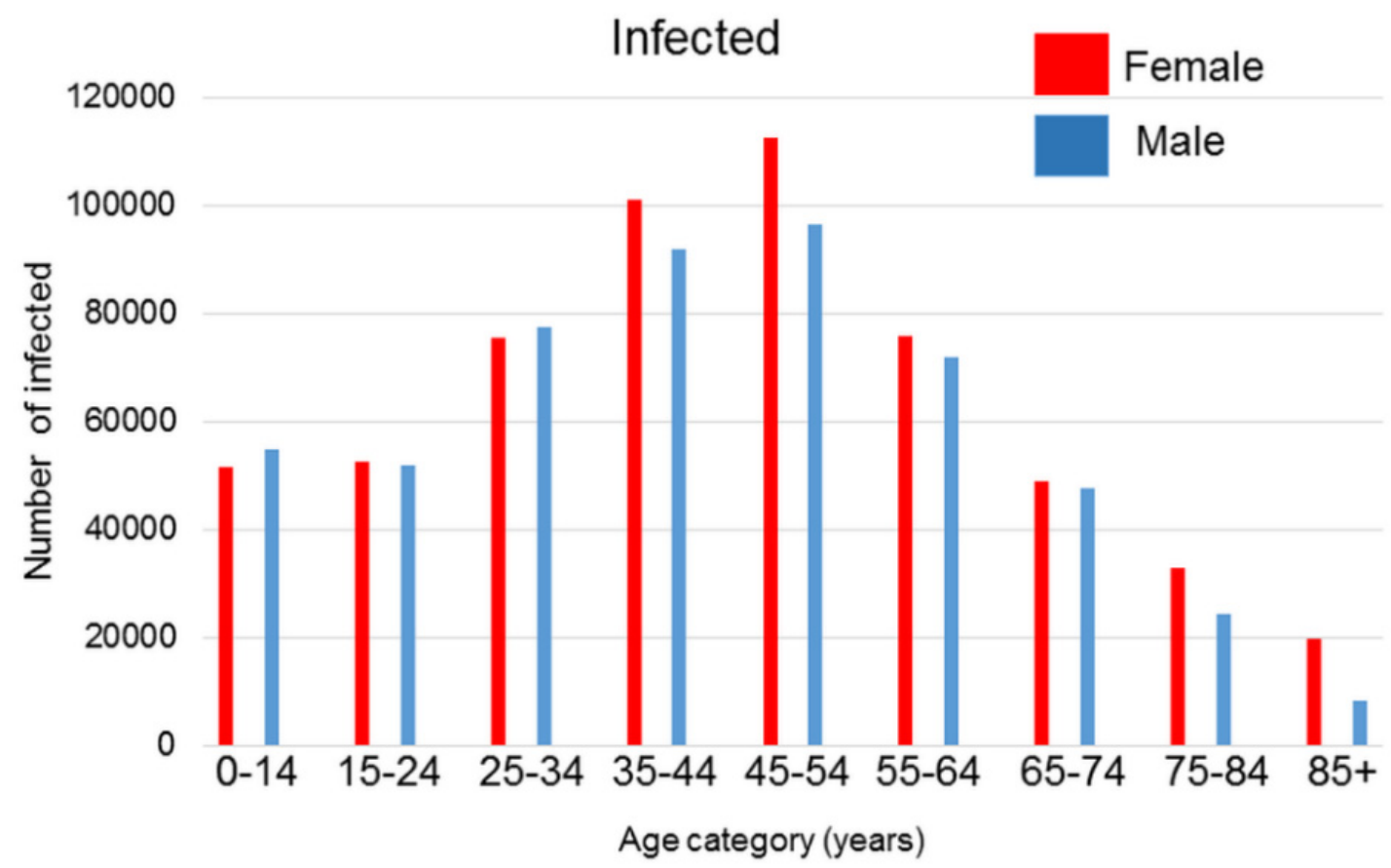

Figure 1. Number of SARS-CoV-2 infections in the Czech Republic until mid-February 2021 according to the data published by the Ministry of Health of the Czech Republic.

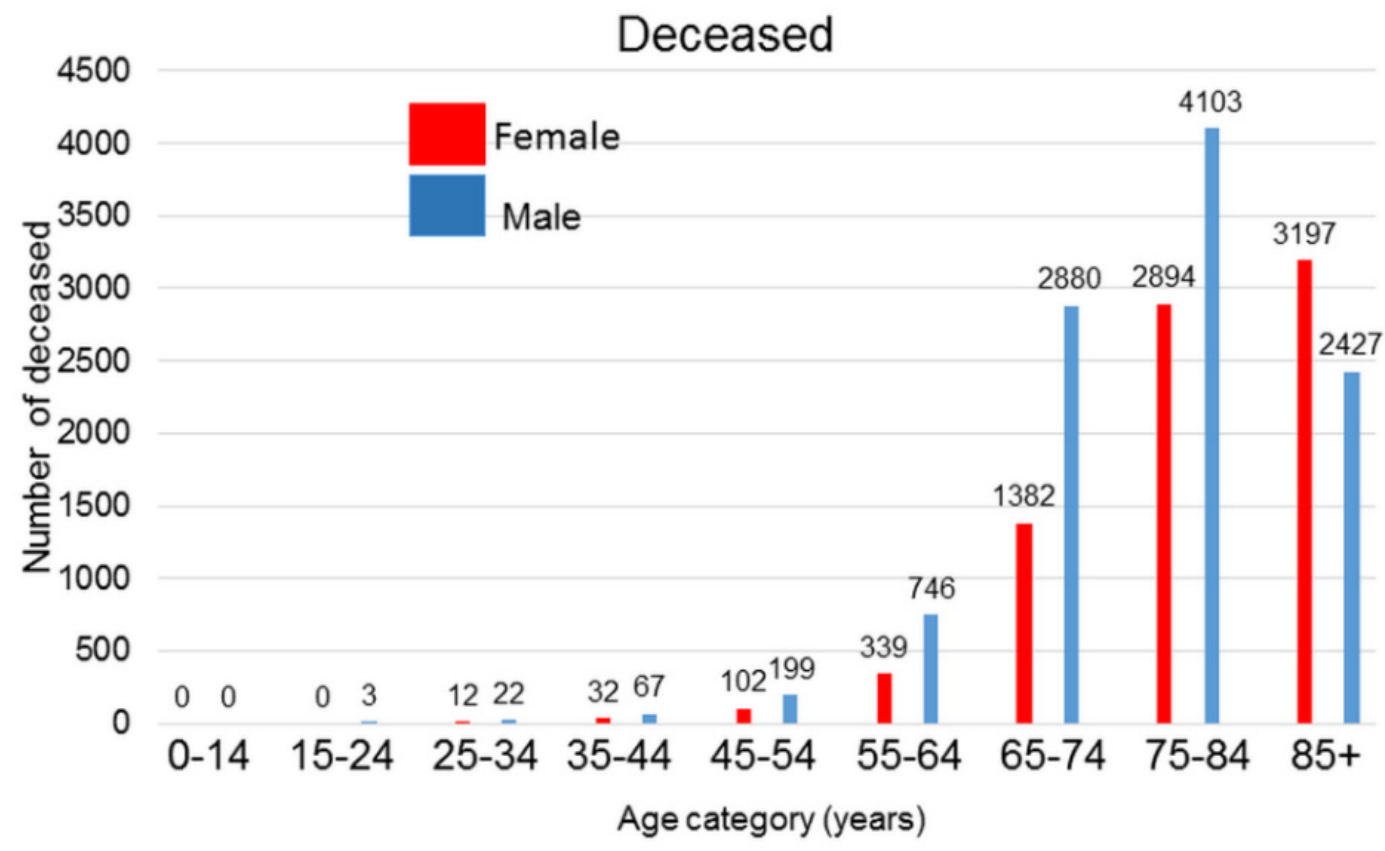

Figure 2. Number of deaths in the Czech Republic until mid-February 2021 according to the data published by the Ministry of Health of the Czech Republic.

The interaction of SARS-CoV-2 with its ACE2 receptor (receptor used by the SARS-CoV-2 virus to enter host cells) activates the ADAM17 membrane protease, which can remove ACE2 from the cell membrane, and soluble ACE2 in the serum negatively 
influences the cardiovascular system [2]. Moreover, ADAM17 also activates TNF $\alpha$ and, through the cleavage of the IL6-receptor, it also stimulates the IL-6 signalling cascade [6,7]. This mechanism seems to be associated with the absence of estrogens and low levels of testosterone in aged males and is likely linked to their unfavourable prognosis following SARS-CoV-2 infection [8]. Thus, the sex-dependent difference and the more severe disease progression resulting in higher mortality of males could also be ascribed to the effect of estrogens in females resulting in lower expression of SARS-CoV-2 receptor $[9,10]$.

On the other hand, the male gender and the presence of androgens could be a predisposing factor for severe COVID-19 cases because androgens appear to ease the entry of the virus into the host cell [11,12]. This observation is supported by an independent study performed in Peru, where male COVID-19 patients with androgenic alopecia suffer from severe COVID-19 more frequently than infected males who do not suffer from this type of alopecia [13]. The protective role of estrogens in COVID-19 is also evident in women suffering from polycystic ovary syndrome. In this condition, with an excess of androgens, women have an increased risk of SARS-CoV-2 compared to the control group [14]. In addition to biological factors, the higher COVID-19 fatality of males is also influenced by behavioural factors such as smoking, alcohol consumption or noncompliance to COVID-19 prevention measures, all of which are generally observed more frequently in males [15].

\section{Physiological Estrogen Receptor-Dependent Effects and Viral Infection Susceptibility}

The difference in susceptibility to viral infection in males and females [16] seems to be dependent on the production of sex hormones in women [17]. These steroids have remarkable effects on a multitude of physiological functions.

The biological functions of estrogens are largely modulated by estrogen receptors known as subtypes alpha $(\mathrm{ER} \alpha)$ and beta $(\mathrm{ER} \beta)$. Estrogen receptors are expressed in numerous cell types of various tissues, including the immune system. During physiological conditions, ERs exist as dimers and are stabilized by the binding of either agonists or antagonists. These receptors reach the cell nucleus and control the transcription of specific target genes by binding to associated DNA regulatory sequences. Estrogen receptors control cells and pathways in the innate and adaptive immune system and regulates immune cell development [18]. Estradiol and ER activity show profound effects on innate immune signaling pathways and myeloid cell development [19].

Moreover, several such hormones may be responsible for the poorer course of COVID19 disease occurring in males [20]. When focusing on the effect of estradiol on human physiology, many authors have observed that this particular steroid hormone significantly influences the respiratory, cardiovascular and immune systems (summarized by BreithauptFallopa et al. [21] and Pinna [22]. Briefly, estradiol decreases recruitment of neutrophils and local cytokine production and possesses an antioedematous effect in the lungs. Estradiol also reduces blood platelet aggregation and increases the number of lymphocytes. This was confirmed mainly for Th1 and virus-specific CD8 T lymphocytes. Therefore, we observe dysregulated immune functions in COVID-19 infected individuals more frequently in males than in females [23].

On the other hand, tamoxifen is an ERM (estrogen-receptor modulator) that is frequently used to treat breast cancer patients. While short-term tamoxifen application could be helpful in anti-COVID-19 therapy, its long-term application may reduce expression of estrogen receptors (ERs). Hence, this therapy can increase the susceptibility to SARS-CoV-2 [24,25]. In order to address this hypothesis, we retrospectively analysed a group of 273 breast cancer patients suffering from triple-negative and HER2-positive cancer from the Department of Oncology (First Faculty of Medicine, Charles University and General Teaching Hospital, Prague). We focused our analysis on the incidence of clinically manifested infection that was later confirmed in symptomatic patients as COVID-19 by PCR. We reviewed the period during the COVID-19 epidemic, specifically between March 2020 and February 2021, when vaccination became broadly available to our patients. These patients received chemotherapy or endocrine treatment combined with trastuzumab. 
Patients on immunotherapy, CKD4/6 inhibitors, everolimus or alpelisib were excluded. Similarly, we excluded patients with cancer duplicity or multiplicity and the patients who were already COVID-19 vaccinated. Our data suggest the influence of tamoxifene on SARSe-CoV -2 clinically manifest infection in our breast cancer patients (Figure 3 ).

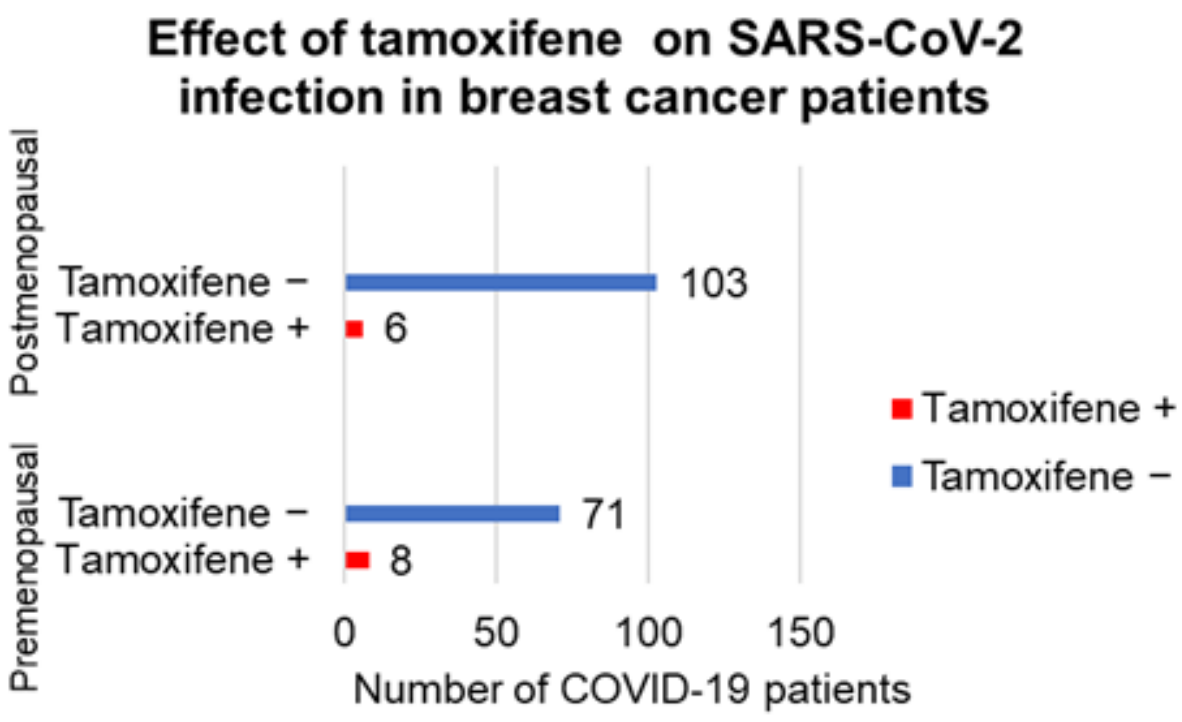

Figure 3. Effect of hormonal therapy of female breast cancer patients with tamoxifene on the sensitivity to SARS-CoV-2 infection. Females treated by this drug were not as sensitive to infection as non-treated patients. The effect of therapy was higher in postmenopausal women without the production of estrogens.

From this point of view, males are predisposed to a more severe course of COVID-19 disease [26]. This observation agrees with the results of a genomic investigation using a gene-set enrichment analysis of normal and SARS-CoV-2-infected human tissue, where estrogen receptors $E R \alpha$ and $\beta$ significantly stimulate the immune response in the infected women. This is in contrast with males, where the immune response is inhibited [27]. Both $\mathrm{ER} \alpha / \beta$ are present in immune cells and their role in COVID-19 may be expected [28,29]. Estrogens stimulate ER $\alpha$ expression in T lymphocytes and activates them [24,30]. The age-dependent loss of ER $\alpha$ in T lymphocytes increases the susceptibility to viruses such is the Coxackie infection [31]. These data may be relevant to the SARS-CoV-2 infection as well.

It should be mentioned here that activities involving the whole-body level function are dependent of the interaction of oestrogens with their specific receptors.

\section{Effect of Oestrogen Receptor Modulators (ERMs) on Viral Replication}

Different modes of action of estrogens and ERMs on viral replication have been described. The mechanism can be either dependent on or independent of the interaction of hormones with their receptors. It has been observed that estradiol interferes with hepatitis B virus infections via the induction of hepatocyte nuclear factor $4 \alpha$ production and interaction with HBV enhancer I [32]. A similar inhibitory effect was confirmed in hepatitis $C$ infections [33,34]. Moreover, these observations are further supported by the evidence of reduced efficiency of hepatitis treatment in postmenopausal women [35]. These mechanisms were also dependent on the interaction of hormones with their receptors. The inhibitory effect of estrogens on replication was documented [36-66]. in a panel of viruses (for particulars see Table 1). 
Table 1. Effect of ERMs on the biology of representative viruses.

\begin{tabular}{|c|c|c|}
\hline $\begin{array}{l}\text { Substance (Relation to } \\
\text { Estrogen) }\end{array}$ & Virus & Effect \\
\hline Estradiol & SARS-CoV-2 & Blocking of virus entry [36] \\
\hline $\begin{array}{c}\text { Bazedoxifene } \\
\text { (agonist/antagonist) }\end{array}$ & $\begin{array}{c}\text { EBOLA } \\
\text { SARS-CoV-2 }\end{array}$ & $\begin{array}{l}\text { Blocking of endolysosomal system [37] } \\
\text { Interaction with SARS-CoV-2 main protease [38] }\end{array}$ \\
\hline Clomiphene (analogue) & $\begin{array}{l}\text { SARS-CoV-2 } \\
\text { EBOLA }\end{array}$ & $\begin{array}{l}\text { Blocking of endolysosomal system [39] } \\
\text { Blocking of virus entry }[37,40-45]\end{array}$ \\
\hline $\begin{array}{c}\text { Cyclofenil } \\
\text { (agonist/antagonist) }\end{array}$ & Dengue, Zika & RNA synthesis inhibition [46] \\
\hline Genestin (analogue) & $\begin{array}{c}\text { Adenoviruses } \\
\text { Bovine herpesvirus } 1 \\
\text { Virus herpes simplex } 1 / 2 \\
\text { Human herpesvirus } 8 \\
\text { Moloney murine leukemia } \\
\text { Rotaviruses } \\
\text { Simian virus } 40 \\
\text { Human cytomegalovirus } \\
\text { Human immunodeficiency } 1\end{array}$ & $\begin{array}{c}\text { Blocking of virus entry [47] } \\
\text { Reduction in virus replication [48] } \\
\text { Blocking of virus entry and translation [49] } \\
\text { Reduction in virus DNA synthesis [50] } \\
\text { Blocking of virus entry [51] }\end{array}$ \\
\hline Genistein (analogue) & $\begin{array}{c}\text { Arenaviruses } \\
\text { Bovine viral diarrhoea } \\
\text { African swine fever virus }\end{array}$ & $\begin{array}{c}\text { Inhibition of tyrosinkinase [52] } \\
\text { Blocking of virus entry and translation [49] } \\
\text { Disruption of DNA synthesis [53] }\end{array}$ \\
\hline Quercetin (analogue) & Adenoviruses & Blocking of virus entry and translation [49] \\
\hline Quinestrol (analogue) & Flaviviruses (ZIKA, Dengue, West Nile) & Reduction in virus RNA synthesis [54] \\
\hline $\begin{array}{c}\text { Raloxifene } \\
\text { (agonist/antagonist) }\end{array}$ & $\begin{array}{c}\text { Flaviviruses (ZIKA, Dengue, West Nile) } \\
\text { EBOLA, SARS-CoV-2 }\end{array}$ & $\begin{array}{l}\text { Reduction in virus RNA synthesis }[54,55] \\
\text { Blocking of virus entry }[44,56-60]\end{array}$ \\
\hline $\begin{array}{c}\text { Ridaifene-b(+XL-147) } \\
\text { (Tamoxifen analogue without } \\
\text { effect on ER) }\end{array}$ & EBOLA & Blocking of virus entry [42] \\
\hline $\begin{array}{c}\text { Tamoxifen } \\
\text { (agonist/antagonist) }\end{array}$ & $\begin{array}{c}\text { MERS } \\
\text { Vesicular stomatitis virus } \\
\text { EBOLA }\end{array}$ & $\begin{array}{c}\text { Inhibition of virus replication [61] } \\
\text { Inhibition of virus replication and activation of } \\
\text { macrophages [62] } \\
\text { Blocking of virus entry }[45,58]\end{array}$ \\
\hline $\begin{array}{l}\text { Toremifene } \\
\text { (agonist/antagonist) }\end{array}$ & $\begin{array}{c}\text { MERS } \\
\text { EBOLA } \\
\text { SARS-CoV-2 }\end{array}$ & $\begin{array}{l}\text { Inhibition of virus replication }[61] \\
\text { Blocking of virus entry }[43,58,63,64] \\
\text { Blocking of virus entry }[65,66]\end{array}$ \\
\hline
\end{tabular}

It seems that estrogens here act independently of their interaction with receptors. What is also noteworthy is that natural and synthetic compounds modulating estrogen receptor activities can be medically relevant. These drugs with ERM activity act as estrogen analogues or agonists (Supplementary Materials Figure S1). However, they can also attenuate the course of viral infection. Unfortunately, the precise molecular mechanisms of action were deciphered only in a few cases and are usually independent of the interaction with the receptor. Clomifene, raloxifene, ridaifene (+XL-147) and toremifene act via attenuation of the interaction of SARS-CoV-2 or EBOLA with their target cells [37,40-44], where some role of the inhibition of SARS- $\mathrm{CoV}-2$ spike protein interaction with receptor ACE2 may be expected $[36,37,39,44,45,67]$. ERMs seem to inhibit the glycan-glycan interaction between the spike protein and ACE2 and so reduces the virus entry to permissive cells $[43,68]$.

Clomiphene, raloxifene and tamoxifen also interact with late endo/lysosomes. This stimulates accumulation of cholesterol and has an inhibitory effect on the release of SARS - CoV -2 and EBOLA RNA from the vesicle. This represents a critical step in virus replication $[39,45,55]$. 
Another compound, genistein, can directly disrupt the replication of viral DNA in the African swine fever virus (ASFV) by interaction with ASFV topoisomerase II [53]. Similarly, quinestrol and raloxifene inhibits the synthesis of SARS-CoV-2 RNA [54].

Cylofenil inhibits assembly and maturation in the Dengue virus [46].

Some candidate drugs can exert several effects in parallel. In addition to targeting virus replication, bazedoxifene can also protect TNF- $\alpha$-dependent damage to endothelial cells in persons suffering from COVID-19. TNF- $\alpha$ is elevated in this disease as an essential bioactive protein of cytokine storm [68]. Bazedoxifene can block TNF- $\alpha$ binding to CD40 expressed on endothelial cells. This action can prevent endothelial injury [32]. Indeed, epidemiological data suggest that patients on anti-TNF- $\alpha$ drugs for rheumatologic conditions are at lower hospitalisation risk than the control population [69].

These data collectively demonstrate that several ERMs possess remarkable broad antiviral activity independent of their interactions with estrogen receptors. Their activities overlap and can have an inhibitory effect on the viral entry, release of nucleic acid from virions encapsulated by endosomes and replication of nucleic acid and virus assembly, which represent the crucial steps of virus infection.

\section{ERMs and Estrogens as Inhibitors of SARS-CoV-2 Proteases}

Among the SARS-CoV-2 components, the viral proteases such as main protease $\left(\mathrm{M}^{\text {pro }}\right)$ and papain-like protease $\left(\mathrm{PL}^{\mathrm{pro}}\right)$ represent molecules critically important in viral replication [70,71]. Proteases, therefore, also offer a potential target for antiviral therapy [72]. A plethora of known protease inhibitors (including but not limited to disulfiram, lopinavir/ritonavir, nelfinavir and danoprevir) can be potentially employed in COVID-19 therapy [70].

Remdesivir, an inhibitor of the viral RNA-dependent RNA polymerase, was used as COVID-19 therapeutic. Interestingly, it is also able to interact with SARS-CoV-2 $\mathrm{M}^{\text {pro }}$ [73].

Some works suggested that ERMs could also be potent inhibitors of SARS-CoV-2 proteases [74], namely isoflavonoids and raloxifene. Among candidate inhibitors of SARS-CoV-2 $\mathrm{M}^{\text {pro }}$, quercetin and other similar flavonoids were identified $[75,76]$.

The possible interactions of ERMs (structures are shown in Supplementary Materials Figure S1) with both SARS- $\mathrm{CoV}-2$ proteases $\mathrm{M}^{\text {pro }}$ and $\mathrm{PL}^{\text {pro }}$ are presented in Table 2 and Figures 4-6.

Chiou and coworkers [77] have reported that raloxifene is a potent inhibitor of SARS $-\mathrm{CoV}-2 \mathrm{M}^{\text {pro }}\left(\mathrm{IC}_{50}=5.61 \mu \mathrm{mol} / \mathrm{L}\right)$. It is known that part of the ERM biological effect lies in their interaction with ER. This results in the question of whether estrogens, or the other ERMs could also interact with $\mathrm{CoV}-2$ proteases. In order to address this question, we used AutoDock Vina [78] to predict the binding affinity of genistin, estrogens and ERMS to $\mathrm{M}^{\text {pro }}$. Based on various interactions, we calculated the binding energy. The docking study implies that ERMs, especially bazedoxifene, display the highest affinity for the SARS-CoV-2 main protease and SARS and the lowest affinity for $\mathrm{CoV}-2$ papain-like protease ( $\mathrm{PL}{ }^{\mathrm{pro}}$ monomer). In the case of estrogens, the values obtained for SARS $-\mathrm{CoV}-2$ $\mathrm{M}^{\text {pro }}$ were comparable with those calculated for their interaction with PL ${ }^{\text {pro }}$ (monomer and trimer) (Table 2, Figures 5 and 6, Supplementary Tables S1-S3 and Figures S2-S22).

These results allow us to postulate the hypothesis that some ERMs, especially bazedoxifene, could display another important therapeutic activity necessary for the treatment of COVID-19 via inhibition of COVID proteases in addition to the inhibition of IL-6 signalling and modulation of ER. The possible inhibitory effect of estrogens against $\mathrm{CoV}-2$ proteases should also be considered when explaining the higher susceptibility of males to COVID-19 than that observed in females. In summary of this section, interaction of ERM including natural estrogens with SARS-CoV-2 proteases can participate in the inhibition of their replication as proposed [72]. 
Table 2. The calculated interaction energy between SARS-CoV-2 proteases and estrogens or ERMs (kcal/mol).

\begin{tabular}{cccc}
\hline Agents & Main Protease & $\begin{array}{c}\text { Papain-Like } \\
\text { Protease (Monomer) }\end{array}$ & $\begin{array}{c}\text { Papain-Like } \\
\text { Protease (Trimer) }\end{array}$ \\
\hline Estradiol & -7.14 & -6.86 & -7.32 \\
\hline Estrane & -7.59 & -6.28 & -7.51 \\
\hline Estriol & -7.9 & -6.43 & -7.82 \\
\hline Estrone & -8.96 & -6.94 & -7.61 \\
\hline Bazedoxifene & -10.13 & -5.54 & -7.69 \\
\hline Genistine & -7.7 & -6.07 & -6.25 \\
\hline Raloxifene & -8.61 & -6.14 & -7.49 \\
\hline
\end{tabular}
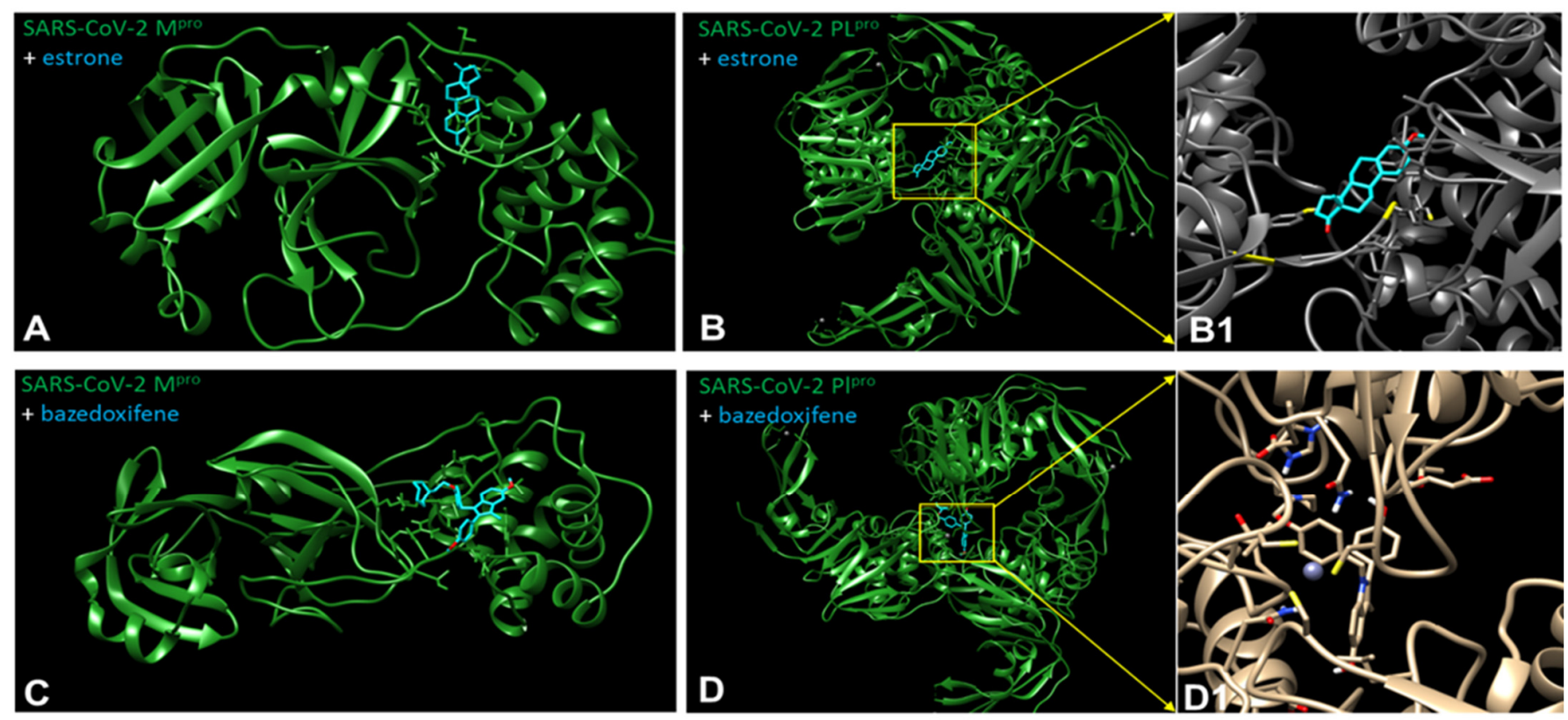

Figure 4. The best docking pose of estrone (above) and bazedoxifene (below) to the SARS-CoV-2 main protease structure $\left(\mathrm{M}^{\mathrm{pro}}\right)(\mathbf{A}, \mathbf{C})$ and papain-like protease (PL $\left.{ }^{\text {pro }}\right)$ trimer (B,B1,D,D1). Pymol representation of the SARS-CoV-2 main protease (PDB id 6y7b) shown as a green ribbon with the secondary structure elements indicated. In blue sticks: the best docking pose for estrone (A) or bazedoxifene $(\mathbf{C})$. The best docking poses of the estrone (B,B1) and bazedoxifene (D,D1) molecule in PL pro trimer (PDB id 6w9c) are localized in the vicinity of the zinc ion present at the central interface of the trimer. 


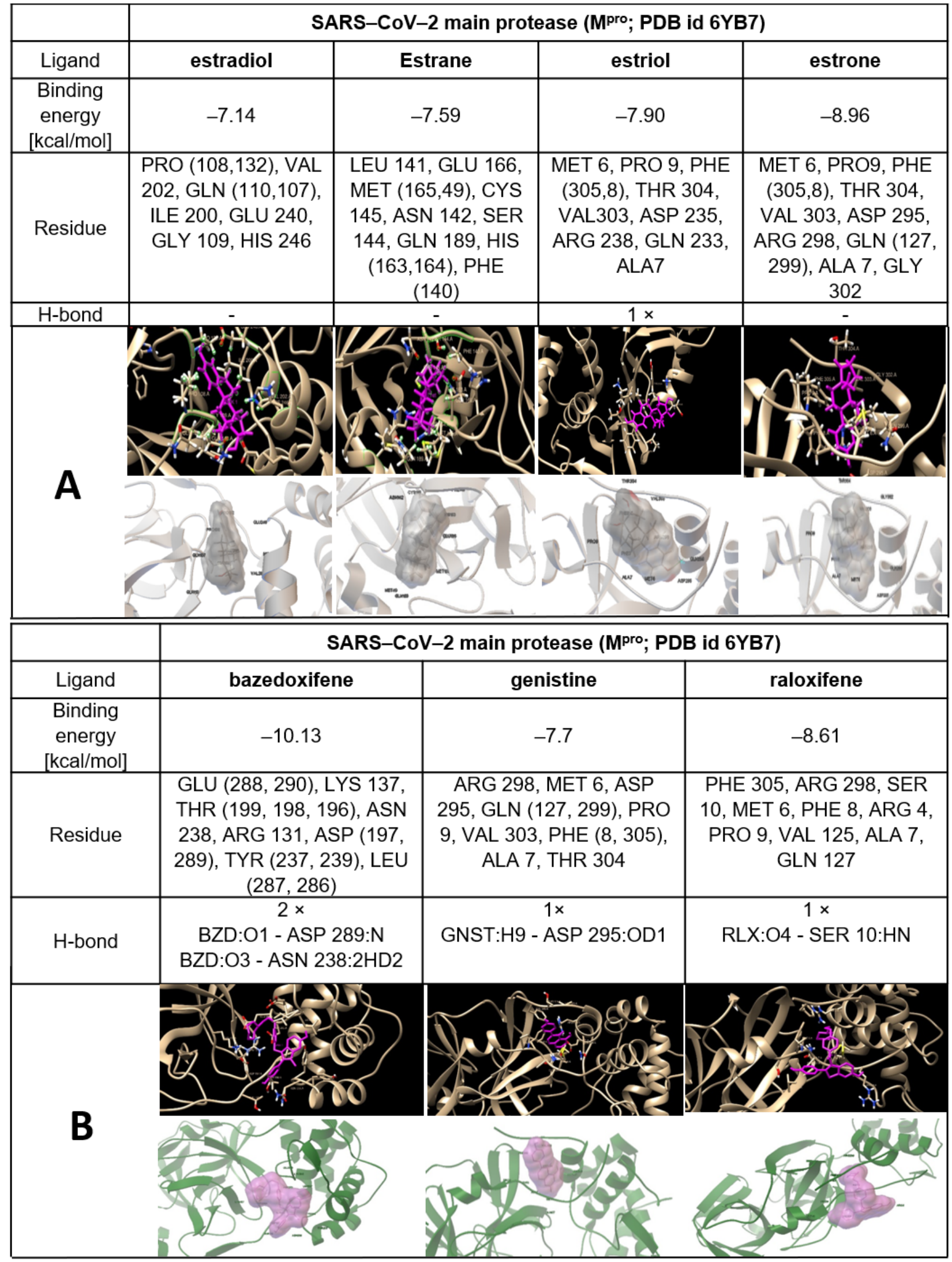

Figure 5. The best docking pose of estrogens (A) and other examples of ERM, such as bazedoxifene, genistein and raloxifene (B) to the SARS-CoV-2 main protease structure $\left(\mathrm{M}^{\mathrm{pro}}\right)$ with characterization of the interaction including hydrogen bonds. 


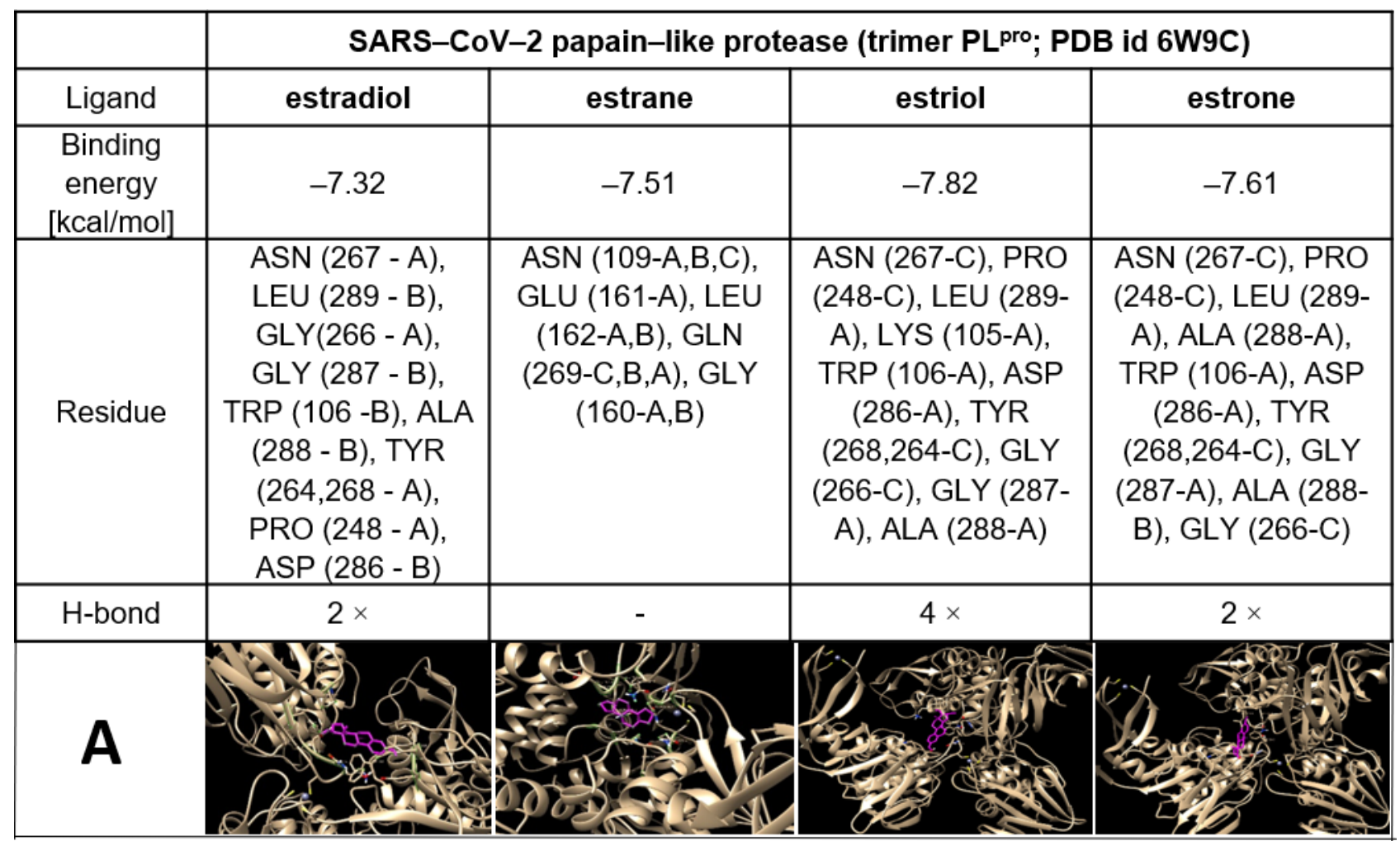

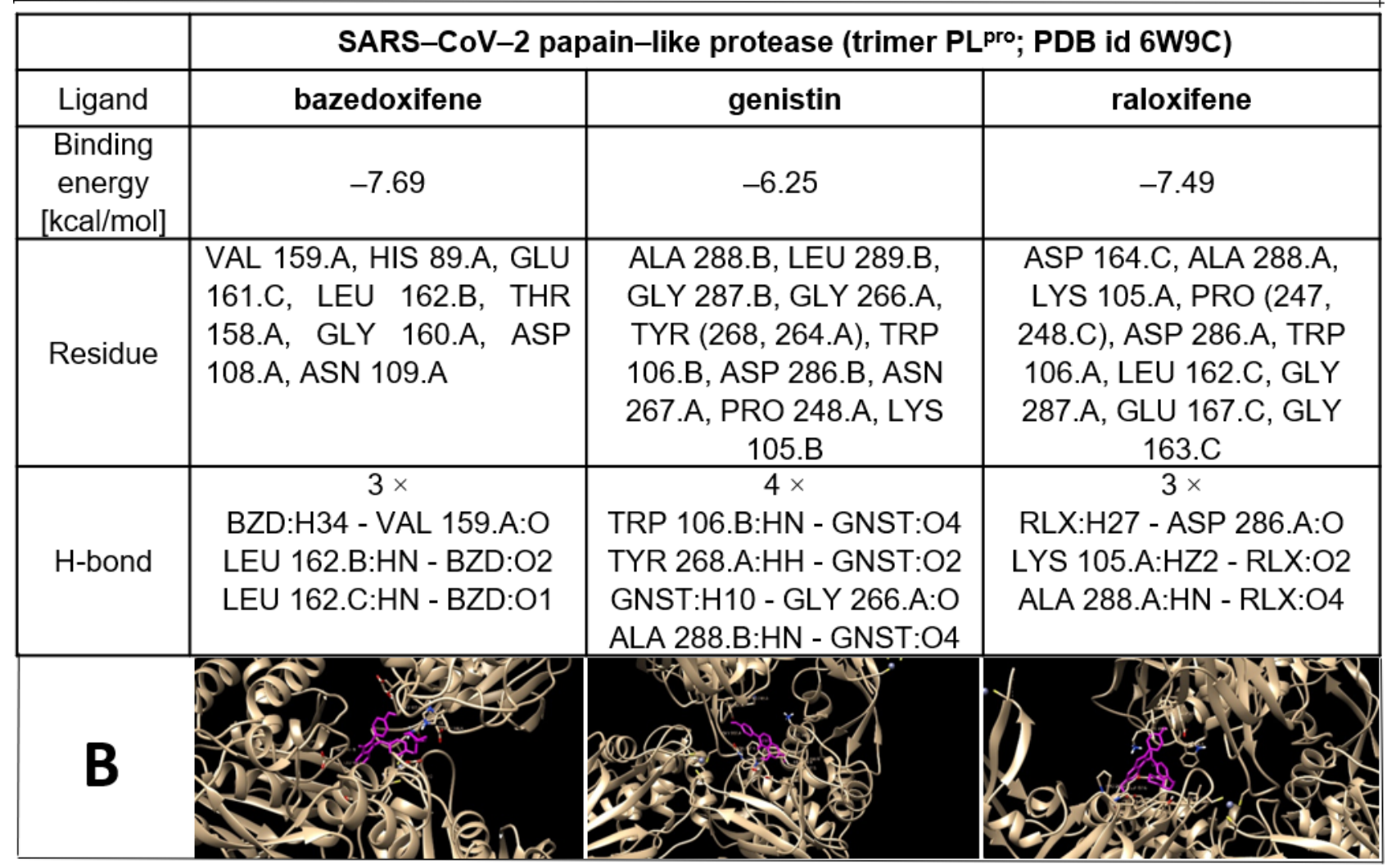

Figure 6. The best docking pose of oestrogens (A) and other examples of ERM such as bazedoxifene, genistin and raloxifene (B) to the SARS-CoV-2 papain-like protease structure (PL ${ }^{\text {pro }}$ ) (trimer form) with characterization of the interaction including hydrogen bonds. 


\section{Antiviral Effect of Estrogens as a Developmental Strategy}

Sex-specific infection rates and sex-related differences in mortality rates have been documented in humans [79]. Indeed, this is a sort of sexual dimorphism. The hormonal regulation becomes highly dynamic during the course of pregnancy. The development of the hormonal milieu of pregnancy has become an increasingly studied area of interest of immunology in recent years [80]. Pregnancy is associated with an alteration in immune priorities characterised by a strengthening of innate immune barriers and a concomitant reduction in adaptive/inflammatory immunity in the later stages of pregnancy [81]. Briefly, all this precise orchestration of the maternal immune system provides protection for the mother and her future offspring from pathogens, while avoiding detrimental immune responses against the allogeneic foetus. Therefore, estrogen-related signalling seems to be part of a developmental strategy potentially providing critical protection for both the mother and the infant in early life.

The estrogen-ER axis represents a fundamental hormonal regulatory axis of the female reproductive system. This essential regulation influences virtually all body parts in females. This article demonstrates that ER-dependent activity predisposes the organism, namely the respiratory, cardiovascular system and innate/adaptive immunity, to be more resistant to viral infection. Moreover, ER-independent functions can minimise viral entry, replication and assembly.

It is well known in clinics that the female organism in fertile age is more resistant to cardiovascular problems and females have more robust immunity [82]. Klein and Flanagan [16] aimed to summarize the sex-related differences in the immune response of males and females. As confirmed in many species, the immune response is more robust in females than in males (data collected from sea urchin, fruit fly, scorpion fly, wall lizard, Eurasian kestrel, great tit, home mouse, Rhesus macaque and humans). It is also consistent with the fact that women develop a stronger response to vaccination [16].

However, women pay for this advantage by a higher proclivity to autoimmune disorders (e.g., Graves' disease, Hashimoto thyroiditis and multiple sclerosis).

The activation of ER also stimulates wound healing. It seems to be a critically important aspect of postpartum healing in mammals [83]. However, this impact is broader and also affects extragenital organs. Interestingly, distinct steps of wound healing, such as epidermal cell proliferation or production of extracellular matrix, are precisely regulated by the timely expression of $\alpha / \beta$ ER [84]. What is noteworthy is that the benefits of the female sex are diminished in female mammals after menopause, when the production of sex hormones decreases [16]. Nevertheless, these lost hormone-dependent functions can be restored to some extent by substitutional estrogen therapy and it is used in clinics routinely.

In the context of this article, raloxifene is clinically used as ERM for the prevention of postmenopausal osteoporosis. Moreover, raloxifene administration also normalises levels of blood lipids and thus reduces cardiovascular risks [85].

From the evolutionary view, the summarized plethora of advantages of estrogen during the fertile age can be interpreted as a sort of protection of the female as a donor and bearer of life. Hormonal substitution has had several relevant applications recently and can substantiate therapeutic interventions available in the future. Furthermore, this hypothesis harmonizes well with the lower mortality in women suffering from COVID-19 [86] and may have therapeutic implications.

\section{Therapeutic Consequences}

COVID-19 can be theoretically influenced by the wide panel of approved therapeutics. This repurposing was suggested for angiotensin II receptor blocker (Losartan), protease inhibitors (lopinavir) or biologics inhibiting the IL-6 signalling cascade (Tocilizumab). Corticoids are routinely employed in practice for their broad ability to suppress the immune response $[87,88]$. Based on extensive knowledge from cancer therapy, inhibitors of sex hormone receptors were also proposed as candidate therapeutics for COVID-19 [25]. As demonstrated in our article, a panel of ERM can be potentially employed [89]. ER of both 
types are expressed, at the protein level, in cells in both sexes and more in females than in males [90]. However, it is sufficient for clinicians to use estrogen modulators in patients of both sexes. ERM therapy in males is possible for a limited period of time without the adverse effect of feminisation. In addition to the receptor-dependent effect of estrogens controlling the immune response, there is also the direct antiviral effect of ERM that is ER-independent.

Searching for possible off-target indications in approved drugs, ERMs were identified as suitable candidates for COVID-19 therapy [88]. A broad panel of ERMs is routinely used in clinical practice to treat conditions ranging from endocrine disorders to cancer. The combination of ERMs with antiandrogen therapy could also be helpful in the COVID-19 treatment. However, the employment of ERMs in anti-COVID-19 therapy requires further research and clinical testing before their introduction to clinics.

Another strategy can be based on targeting the regulation of androgens. This can result in their temporarily decreased production in COVID-19 patients. This principle was proposed and tested in animal experiments and in a limited clinical study performed in COVID-19 patients [91-93].

Concerning the hypothesised multiple therapeutic effects of ERMs, bazedoxifene and raloxifene can be good examples. These drugs are very similar with respect to their chemical structures. Both are used for the treatment of postmenopausal osteoporosis [94,95]. As mentioned above, both possess an inhibitory effect on virus replication in which they can interact with viral proteases (Table 2). They also interact with a signal transducer (glycoprotein 130) and, by this mechanism, they attenuate the interaction of IL-6 with its receptor $[96,97]$. This activity seems to have some anticancer effect. IL-6 is a critical component in the initiation of cytokine storm/hyperinflammatory syndrome that represents the deadly complication of COVID-19 [98-100]. Although results are not unambiguous, anti-IL-6 receptor therapy with therapeutic antibody Tocilizumab demonstrated promising effects [101-103]. Moreover, bazedoxifene and raloxifene estrogen-like activity and their ability to activate ER may result in beneficial effects on the COVID-19 patients (namely on the lungs, immunity and vascular permeability). The potential effects of ERM on COVID-19 are summarised in Table 3 and in Figure 7, where we demonstrate the effect of ERMs on the organism of infected person and on the virus replication including the effect of ER occupation by suitable ERMs.

Table 3. Summarization of the potential role of ERMs including estrogen in COVID-19.

\begin{tabular}{cccc}
\hline Function & Potential Effect of ERM & $\begin{array}{c}\text { Dependence on ERM } \\
\text { Binding to ER }\end{array}$ & $\begin{array}{c}\text { Potential } \\
\text { Clinical/Therapeutic Effect }\end{array}$ \\
\hline Pulmonary function & Stimulated & Yes [21,29] & Yes \\
\hline ACE2 expression in airways & Reduced & Yes [9] & Yes [21] \\
\hline Cardiovascular function & Stimulated & No [21] & Yes \\
\hline Vascular endothelium injury & Reduced & Yes/No [21] & Yes \\
\hline $\begin{array}{c}\text { Increased vascular } \\
\text { permeability }\end{array}$ & Reduced & Yes [16] & Yes \\
\hline $\begin{array}{c}\text { Smm response against }- \text { CoV-2 } \\
\text { Sensitivity to vaccination }\end{array}$ & Stimulated \\
including IL-6 & Stimulated & Yes [16] & Yes [16,68] \\
\hline IL-6 binding to receptor & Reduced & No [96,99] & Yes \\
\hline
\end{tabular}


Table 3. Cont.

\begin{tabular}{cccc}
\hline Function & Potential Effect of ERM & $\begin{array}{c}\text { Dependence on ERM } \\
\text { Binding to ER }\end{array}$ & $\begin{array}{c}\text { Potential } \\
\text { Clinical/Therapeutic Effect }\end{array}$ \\
\hline Virus replication (virus entry) & Reduced & Yes/No (see Table 1) & Yes \\
\hline $\begin{array}{c}\text { Virus replication (release of } \\
\text { RNA from endosome) }\end{array}$ & Reduced & No (see Table 1) & Yes \\
\hline $\begin{array}{c}\text { Virus replication (inhibition of } \\
\text { proteases) }\end{array}$ & Reduced & No (see Table 1, [77]) & Yes \\
\hline
\end{tabular}

\section{EFFECT OF ERM ON COVID-19}

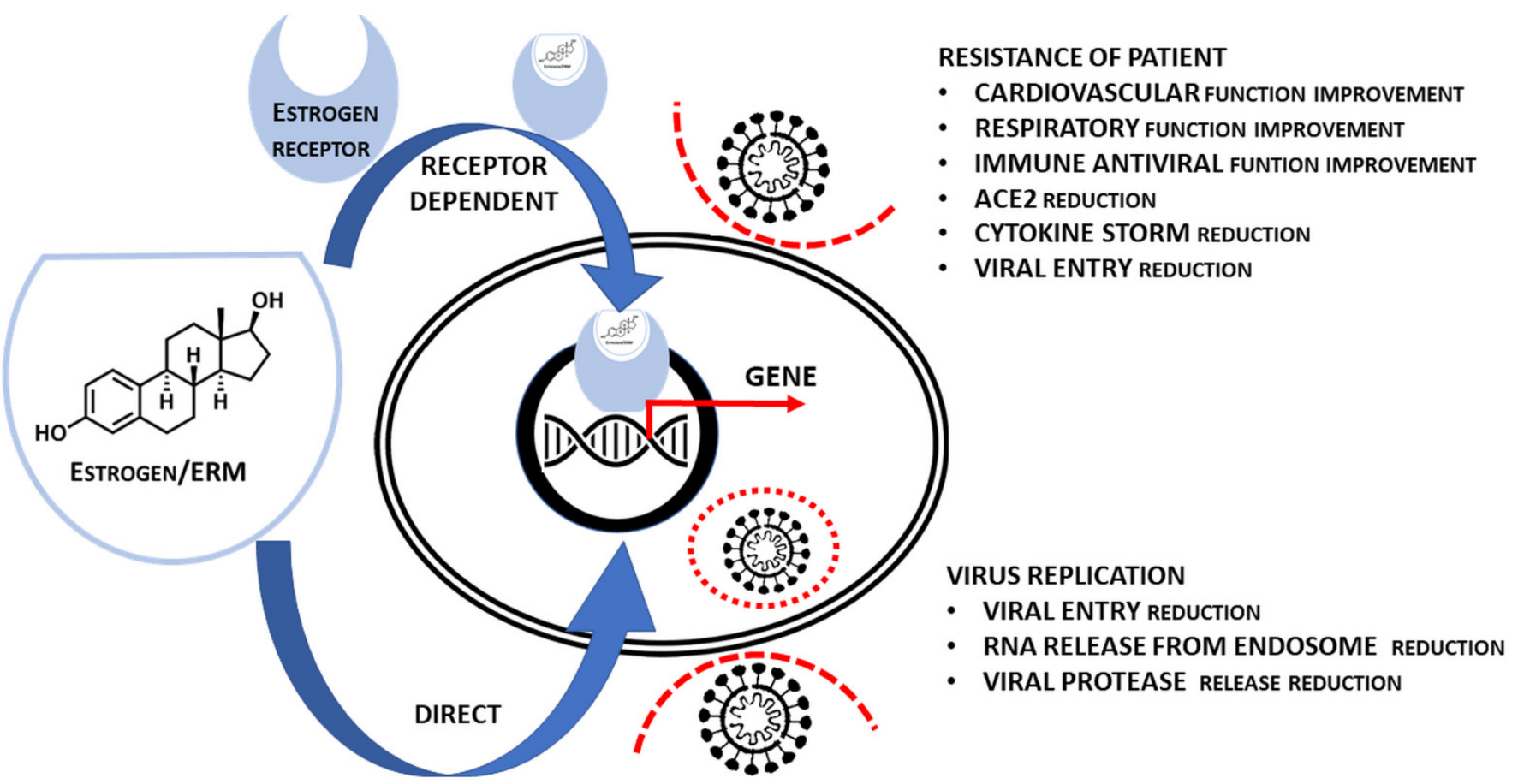

Figure 7. Schematic presentation of the proposed receptor-dependent and independent effect of ERMs on the SARS-CoV-2 infection.

The use of ERM, perhaps in combination with other therapeutics, can extend the panel of anti-COVID-19 therapeutics.

7. Experimental Part Describing Procedures of Molecular Docking of SARS-CoV-2 Proteases with Estrogens and ERM

For docking studies, the model complexes of SARS-CoV-2 proteases with estrogens and drugs have been created. The three-dimensional structures of proteases were retrieved from the protein data bank database with PDB ID (id 6YB7 for SARS-CoV-2 main protease and id $6 \mathrm{~W} 9 \mathrm{C}$ for SARS $-\mathrm{CoV}-2$ papain-like protease). The three-dimensional structures of estrogens and drugs with estrogenic effects (Supplementary Figures S2-S22) were obtained from PDB (for estrogens) and PubChem (for drugs) databases. The structures from the PubChem database were saved, using the UCSF Chimera software, as pdb files. During the docking process, one molecule was taken as a receptor and another considered as a ligand and we took a grid box for the receptor. In this study, the protease's three-dimensional structure was taken as a receptor. The estrogens (estradiol, estrone, estrange and estriol) and ERMs (bazedoxifene, raloxifene and genistein) were considered as ligands. We used AutoDockTools (ADT) in our in silico analysis [78] to prepare receptors and ligands. UCSF Chimera was used to remove two chains from the SARS-CoV-2 papain-like protease 
(trimeric) to obtain the SARS-CoV-2 papain-like protease (monomeric). Non-essential water molecules, including hetero atoms, were extracted before continuing with the docking test. However, we used ADT for the molecule's preparation for docking in our analysis. For all our molecules, we used ADT to remove water molecules and solvent residues; we also used a software for adding polar hydrogens and partial chargers to the structure. Molecular docking was finally performed by ADT.

We studied the interaction of proteases with estrogens and ERMs using ADT and UCSF Chimera to identify the protein-ligand binding site. We also tried to define important properties of the new complexes, such as the binding energy between the protein and ligand, the existence of hydrogen bonds and $\pi-\pi$ interactions and the presence of amino acids playing a role in the process of binding. The three-dimensional structures were converted to pdbqt format using ADT. The grid box size $126 \times 126 \times 126$ and the centre was selected that covered thes maximum of the surface of the receptor.

After AutoGrid and AutoDock commands we found ten conformations and selected one best based on the power of binding energy and number of $\mathrm{H}$-bonds. The better binding sites (conformations), obtained from the docking process, were found with ADT by function "analysis-conformation-ranked by energy". After that, we created pdb files of the obtained complexes for the following study of molecules in the UCSF Chimera software [104]. ADT was used to assess the binding affinity of the estrogens to the proteases. In this study, we carried out docking for estradiol, estrone, estrane, estriol, bazedoxifene, raloxifene and genistein. By ADT, we detected information about the binding energy, $\mathrm{H}$-bonds and the existence of $\pi-\pi$ interactions. By using the UCSF Chimera software, we obtained information about the binding pockets, such as complete information on what amino acids are involved in the binding process [104]. Moreover, the UCSF Chimera software allowed us to render pictures and label amino acids on them for better visualisation of the binding pockets. Complete information with images is given in separate documents below.

\section{Conclusions}

This paper demonstrates the potential to employ estrogens and modulators of estrogen receptor in COVID-19 therapy.

Supplementary Materials: The following are available online at https:/ / www.mdpi.com/article/10 $.3390 /$ ijms22126551/s1.

Author Contributions: Conceptualization, K.S.J., J.B. and M.J.; methodology, N.A., F.V., Z.K. and R.K.; resources, P.T., B.D. and L.L.; preparation, L.L., J.B., D.R., A.T. and B.D.; writing-review and editing, K.S.J., J.B. and M.J.; visualization, M.J.; supervision, K.S.J.; funding acquisition, K.S.J. All authors have read and agreed to the published version of the manuscript.

Funding: This research was funded by the Ministry of Education, Youth and Sport of the Czech Republic, project "Centre for Tumour Ecology - Research of the Cancer Microenvironment Supporting Cancer Growth and Spread", No. CZ.02.1.01/0.0/0.0/16_019/0000785 and by Charles University, project PROGRES Q28.

Acknowledgments: The authors are grateful to Šárka Takáčová for English and grammar revision.

Conflicts of Interest: K.S.J., M.J., D.R. and J.B. cooperates with Oxygen Biotech LLC 108 W 13th St. Wilmington DE 19801. This company had no role in the design of the study; in the collection, analyses or interpretation of data; in the writing of the manuscript or in the decision to publish the results. Other authors, i.e., N.A., F.V., P.T., Z.K., R.K., L.L., A.T. and B.D. declare no conflicts of interest.

\section{Abbreviations}




$\begin{array}{ll}\text { ER } & \text { Estrogen receptor } \\ \text { ERM } & \text { Estrogen receptor modulator } \\ \text { HBV } & \text { Hepatitis B virus } \\ \text { IL-6 } & \text { Interleukin-6 } \\ \text { Mpro } & \text { Main protease } \\ \text { MERS } & \text { Middle East respiratory syndrome } \\ \text { PLpro } & \text { Papain-like protease } \\ \text { SARS } & \text { Severe acute respiratory syndrome } \\ \text { SARS-CoV-2 } & \text { Severe acute respiratory syndrome-related coronavirus } \\ \text { TNF- } \alpha & \text { Tumor necrosis factor- } \alpha\end{array}$

\section{References}

1. Costeira, R.; Lee, K.A.; Murray, B.; Christiansen, C.; Castillo-Fernandez, J.; Lochlainn, M.N.; Pujol, J.C.; Macfarlane, H.; Kenny, L.C.; Buchan, I.; et al. Estrogen and COVID-19 symptoms: Associations in women from the COVID symptom study. medRxiv 2020. [CrossRef]

2. Viveiros, A.; Rasmuson, J.; Vu, J.; Mulvagh, S.L.; Yip, C.Y.Y.; Norris, C.M.; Oudit, G.Y. Sex differences in COVID-19: Candidate pathways, genetics of ACE2, and sex hormones. Am. J. Physiol. Heart Circ. Physiol. 2021, 320, H296-H304. [CrossRef]

3. Channappanavar, R.; Fett, C.; Mack, M.; ten Eyck, P.P.; Meyerholz, D.K.; Perlman, S. Sex-based differences in susceptibility to severe acute respiratory syndrome coronavirus infection. J. Immunol. 2017, 198, 4046-4053. [CrossRef]

4. Al-kuraishy, H.M.; Al-Gareeb, A.I.; Faidah, H.; Al-Maiahy, T.J.; Cruz-Martins, N.; Batiha, G.E.S. The looming effects of estrogen in covid-19: A rocky rollout. Front. Nutr. 2021, 8, 649128. [CrossRef]

5. Sha, J.; Qie, G.; Yao, Q.; Sun, W.; Wang, C.; Zhang, Z.; Wang, X.; Wang, P.; Jiang, J.; Bai, X.; et al. Sex differences on clinical characteristics, severity, and mortality in adult patients with COVID-19: A multicentre retrospective study. Front. Med. 2021, 8, 607059. [CrossRef]

6. Gooz, M. ADAM-17: The enzyme that does it all. Crit. Rev. Biochem. Mol. Biol. 2010, 45, 146-169. [CrossRef]

7. Lacina, L.; Brábek, J.; Král, V.; Kodet, O.; Smetana, K. Interleukin-6: A molecule with complex biological impact in cancer. Histol. Histopathol. 2019, 34. [CrossRef]

8. Giagulli, V.A.; Guastamacchia, E.; Magrone, T.; Jirillo, E.; Lisco, G.; de Pergola, G.; Triggiani, V. Worse progression of COVID-19 in men: Is testosterone a key factor? Andrology 2021, 9, 53-64. [CrossRef] [PubMed]

9. Stelzig, K.E.; Canepa-Escaro, F.; Schiliro, M.; Berdnikovs, S.; Prakash, Y.S.; Chiarella, S.E. Estrogen regulates the expression of SARS-CoV-2 receptor ACE2 in differentiated airway epithelial cells. Am. J. Physiol. Lung Cell. Mol. Physiol. 2020, 318. [CrossRef] [PubMed]

10. Wang, Q.; Liu, J.; Shao, R.; Han, X.; Su, C.; Lu, W. Risk and clinical outcomes of COVID-19 in patients with rheumatic diseases compared with the general population: A systematic review and meta-analysis. Rheumatol. Int. 2021, 41, 851-861. [CrossRef] [PubMed]

11. Moradi, F.; Enjezab, B.; Ghadiri-Anari, A. The role of androgens in COVID-19. Diabetes Metab. Syndr. Clin. Res. Rev. 2020, 14, 2003-2006. [CrossRef]

12. Vahedian-Azimi, A.; Pourhoseingholi, M.A.; Saberi, M.; Behnam, B.; Sahebkar, A. Gender susceptibility to COVID-19 mortality: Androgens as the usual suspects? In Advances in Experimental Medicine and Biology; Springer: Berlin/Heidelberg, Germany, 2021; Volume 1321, pp. 261-264.

13. Alopecia and Severity of COVID-19: A Cross-Sectional Study in Peru-PubMed. Available online: https://pubmed.ncbi.nlm.nih. gov/33664171/ (accessed on 10 May 2021).

14. Subramanian, A.; Anand, A.; Adderley, N.J.; Okoth, K.; Toulis, K.A.; Gokhale, K.; Sainsbury, C.; O’Reilly, M.W.; Arlt, W.; Nirantharakumar, K. Increased COVID-19 infections in women with polycystic ovary syndrome: A population-based study. Eur. J. Endocrinol. 2021, 184, 637-645. [CrossRef]

15. Chanana, N.; Palmo, T.; Sharma, K.; Kumar, R.; Graham, B.B.; Pasha, Q. Sex-derived attributes contributing to SARS-CoV-2 mortality. Am. J. Physiol. Endocrinol. Metab. 2020, 319, E562-E567. [CrossRef]

16. Klein, S.L.; Flanagan, K.L. Sex differences in immune responses. Nat. Rev. Immunol. 2016, 16, 626-638. [CrossRef]

17. Forsyth, K.S.; Anguera, M.C. Time to get ill: The intersection of viral infections, sex, and the X chromosome. Curr. Opin. Physiol. 2021, 19, 62-72. [CrossRef] [PubMed]

18. Yakimchuk, K.; Jondal, M.; Okret, S. Estrogen receptor $\alpha$ and $\beta$ in the normal immune system and in lymphoid malignancies. Mol. Cell. Endocrinol. 2013, 375, 121-129. [CrossRef] [PubMed]

19. Kovats, S. Estrogen receptors regulate innate immune cells and signaling pathways. Cell. Immunol. 2015, 294, 63-69. [CrossRef] [PubMed]

20. Wray, S.; Arrowsmith, S. The physiological mechanisms of the sex-based difference in outcomes of COVID19 infection. Front. Physiol. 2021, 12, 71. [CrossRef] [PubMed]

21. Breithaupt-Faloppa, A.C.; de Jesus Correia, C.; Prado, C.M.; Stilhano, R.S.; Ureshino, R.P.; Moreira, L.F.P. 17b-Estradiol, a Potential Ally to Alleviate SARS-CoV-2 Infection. Clinics 2020, 75, 1-8. [CrossRef]

22. Pinna, G. Sex and COVID-19: A protective role for reproductive steroids. Trends Endocrinol. Metab. 2021, 32, 3-6. [CrossRef] 
23. Zhao, G.; Xu, Y.; Li, J.; Cui, X.; Tan, X.; Zhang, H.; Dang, L. Sex differences in immune responses to SARS-CoV-2 in patients with COVID-19. Biosci. Rep. 2021, 41. [CrossRef]

24. Vatansev, H.; Kadiyoran, C.; Cumhur Cure, M.; Cure, E. COVID-19 infection can cause chemotherapy resistance development in patients with breast cancer and tamoxifen may cause susceptibility to COVID-19 infection. Med. Hypotheses 2020, $143,110091$. [CrossRef]

25. Bravaccini, S.; Fonzi, E.; Tebaldi, M.; Angeli, D.; Martinelli, G.; Nicolini, F.; Parrella, P.; Mazza, M. Estrogen and androgen receptor inhibitors: Unexpected allies in the fight against COVID-19. Cell Transplant. 2021, 30. [CrossRef]

26. Acheampong, D.O.; Barffour, I.K.; Boye, A.; Aninagyei, E.; Ocansey, S.; Morna, M.T. Male predisposition to severe COVID-19: Review of evidence and potential therapeutic prospects. Biomed. Pharmacother. 2020, 131, 110748. [CrossRef]

27. Feng, Q.; Li, L.; Wang, X. Identifying pathways and networks associated with the SARS-CoV-2 cell receptor ACE2 based on gene expression profiles in normal and SARS-CoV-2-infected human tissues. Front. Mol. Biosci. 2020, 7, 568954. [CrossRef] [PubMed]

28. Kadel, S.; Kovats, S. Sex hormones regulate innate immune cells and promote sex differences in respiratory virus infection. Front. Immunol. 2018, 9, 1653. [CrossRef]

29. Millas, I.; Duarte Barros, M. Estrogen receptors and their roles in the immune and respiratory systems. Anat. Rec. 2021. [CrossRef] [PubMed]

30. Li, Y.; Jerkic, M.; Slutsky, A.S.; Zhang, H. Molecular mechanisms of sex bias differences in COVID-19 mortality. Crit. Care 2020, 24, 405. [CrossRef]

31. Koenig, A.; Buskiewicz, I.; Huber, S.A. Age-associated changes in estrogen receptor ratios correlate with increased female susceptibility to coxsackievirus B3-induced myocarditis. Front. Immunol. 2017, 8, 1585. [CrossRef]

32. Wang, S.H.; Yeh, S.H.; Lin, W.H.; Yeh, K.H.; Yuan, Q.; Xia, N.S.; Chen, D.S.; Chen, P.J. Estrogen receptor $\alpha$ represses transcription of HBV genes via interaction with hepatocyte nuclear factor $4 \alpha$. Gastroenterology 2012, 142. [CrossRef] [PubMed]

33. Ulitzky, L.; Lafer, M.M.; KuKuruga, M.A.; Silberstein, E.; Cehan, N.; Taylor, D.R. A new signaling pathway for HCV inhibition by estrogen: GPR30 activation leads to cleavage of occludin by MMP-9. PLoS ONE 2016, 11, e0145212. [CrossRef]

34. Magri, A.; Barbaglia, M.N.; Foglia, C.Z.; Boccato, E.; Burlone, M.E.; Cole, S.; Giarda, P.; Grossini, E.; Patel, A.H.; Minisini, R.; et al. 17, $\beta$-estradiol inhibits hepatitis C virus mainly by interference with the release phase of its life cycle. Liver Int. 2016, 37, 669-677. [CrossRef]

35. Villa, E.; Karampatou, A.; Camm, C.; di Leo, A.; Luongo, M.; Ferrari, A.; Petta, S.; Losi, L.; Taliani, G.; Trande, P.; et al. Early menopause is associated with lack of response to antiviral therapy in women with chronic hepatitis C. Gastroenterology 2011, 140, 818-829.e2. [CrossRef]

36. Lemes, R.M.R.; Costa, A.J.; Bartolomeo, C.S.; Bassani, T.B.; Nishino, M.S.; da Silva Pereira, G.J.; Smaili, S.S.; de Barros Maciel, R.M.; Braconi, C.T.; da Cruz, E.F.; et al. 17ß-estradiol reduces SARS-CoV-2 infection in vitro. Physiol. Rep. 2021, 9, e14707. [CrossRef]

37. Penny, C.J.; Vassileva, K.; Jha, A.; Yuan, Y.; Chee, X.; Yates, E.; Mazzon, M.; Kilpatrick, B.S.; Muallem, S.; Marsh, M.; et al. Mining of ebola virus entry inhibitors identifies approved drugs as two-pore channel pore blockers. Biochim. Biophys. Acta Mol. Cell Res. 2019, 1866, 1151-1161. [CrossRef] [PubMed]

38. Jeon, S.; Ko, M.; Lee, J.; Choi, I.; Byun, S.Y.; Park, S.; Shum, D.; Kim, S. Identification of antiviral drug candidates against SARS-CoV-2 from FDA-approved drugs. Antimicrob. Agents Chemother. 2020, 64. [CrossRef] [PubMed]

39. Ghasemnejad-Berenji, M.; Pashapour, S.; Ghasemnejad-Berenji, H. Therapeutic potential for clomiphene, a selective estrogen receptor modulator, in the treatment of COVID-19. Med. Hypotheses 2020, 145, 110354. [CrossRef]

40. Nelson, E.A.; Barnes, A.B.; Wiehle, R.D.; Fontenot, G.K.; Hoenen, T.; White, J.M. Clomiphene and its isomers block ebola virus particle entry and infection with similar potency: Potential therapeutic implications. Viruses 2016, 8, 206. [CrossRef] [PubMed]

41. Calderone, A.; Menichetti, F.; Santini, F.; Colangelo, L.; Lucenteforte, E.; Calderone, V. Selective estrogen receptor modulators in COVID-19: A possible therapeutic option? Front. Pharmacol. 2020, 11, 1085. [CrossRef] [PubMed]

42. Cooper, L.; Schafer, A.; Li, Y.; Cheng, H.; Medegan Fagla, B.; Shen, Z.; Nowar, R.; Dye, K.; Anantpadma, M.; Davey, R.A.; et al. Screening and reverse-engineering of estrogen receptor ligands as potent pan-filovirus inhibitors. J. Med. Chem. 2020, 63, 11085-11099. [CrossRef]

43. Martin, W.R.; Cheng, F. Repurposing of FDA-approved toremifene to treat COVID-19 by blocking the spike glycoprotein and NSP14 of SARS-CoV-2. J. Proteome Res. 2020, 19, 4670-4677. [CrossRef] [PubMed]

44. Hong, S.; Chang, J.O.; Jeong, K.; Lee, W. Raloxifene as a treatment option for viral infections. J. Microbiol. 2021, 59, $124-131$. [CrossRef]

45. Fan, H.; Du, X.; Zhang, J.; Zheng, H.; Lu, X.; Wu, Q.; Li, H.; Wang, H.; Shi, Y.; Gao, G.; et al. Selective inhibition of ebola entry with selective estrogen receptor modulators by disrupting the endolysosomal calcium. Sci. Rep. 2017, 7. [CrossRef]

46. Tohma, D.; Tajima, S.; Kato, F.; Sato, H.; Kakisaka, M.; Hishiki, T.; Kataoka, M.; Takeyama, H.; Lim, C.K.; Aida, Y.; et al. An estrogen antagonist, cyclofenil, has anti-dengue-virus activity. Arch. Virol. 2019, 164, 225-234. [CrossRef] [PubMed]

47. Li, E.; Stupack, D.G.; Brown, S.L.; Klemke, R.; Schlaepfer, D.D.; Nemerow, G.R. Association of P130(CAS) with phosphatidylinositol3-OH kinase mediates adenovirus cell entry. J. Biol. Chem. 2000, 275, 14729-14735. [CrossRef] [PubMed]

48. Akula, S.M.; Hurley, D.J.; Wixon, R.L.; Wang, C.; Chase, C.C.L. Effect of genistein on replication of bovine herpesvirus type 1. Am. J. Vet. Res. 2002, 63, 1124-1128. [CrossRef]

49. Andres, A.; Donovan, S.M.; Kuhlenschmidt, M.S. Soy isoflavones and virus infections. J. Nutr. Biochem. 2009, $20,563-569$. [CrossRef] [PubMed] 
50. Evers, D.L.; Chao, C.F.; Wang, X.; Zhang, Z.; Huong, S.M.; Huang, E.S. Human cytomegalovirus-inhibitory flavonoids: Studies on antiviral activity and mechanism of action. Antivir. Res. 2005, 68, 124-134. [CrossRef] [PubMed]

51. Stantchev, T.S.; Markovic, I.; Telford, W.G.; Clouse, K.A.; Broder, C.C. The tyrosine kinase inhibitor genistein blocks HIV-1 infection in primary human macrophages. Virus Res. 2007, 123, 178-189. [CrossRef]

52. Vela, E.M.; Bowick, G.C.; Herzog, N.K.; Aronson, J.F. Genistein treatment of cells inhibits arenavirus infection. Antivir. Res. 2008, 77, 153-156. [CrossRef]

53. Arabyan, E.; Hakobyan, A.; Kotsinyan, A.; Karalyan, Z.; Arakelov, V.; Arakelov, G.; Nazaryan, K.; Simonyan, A.; Aroutiounian, R.; Ferreira, F.; et al. Genistein inhibits African swine fever virus replication in vitro by disrupting viral DNA synthesis. Antivir. Res. 2018, 156, 128-137. [CrossRef] [PubMed]

54. Eyr, N.S.; Kirb, E.N.; Anfiteatr, D.R.; Bracho, G.; Russ, A.G.; Whit, P.A.; Aloi, A.L.; Bear, M.R. Identification of estrogen receptor modulators as inhibitors of flavivirus infection. Antimicrob. Agents Chemother. 2020, 64. [CrossRef] [PubMed]

55. Galindo, I.; Garaigorta, U.; Lasala, F.; Cuesta-Geijo, M.A.; Bueno, P.; Gil, C.; Delgado, R.; Gastaminza, P.; Alonso, C. Antiviral drugs targeting endosomal membrane proteins inhibit distant animal and human pathogenic viruses. Antivir. Res. 2021, 186 [CrossRef] [PubMed]

56. Rasaeifar, B.; Gomez-Gutierrez, P.; Perez, J.J. Molecular features of non-selective small molecule antagonists of the bradykinin receptors. Pharmaceuticals 2020, 13, 259. [CrossRef] [PubMed]

57. Schultz, B.; Zaliani, A.; Ebeling, C.; Reinshagen, J.; Bojkova, D.; Lage-Rupprecht, V.; Karki, R.; Lukassen, S.; Gadiya, Y.; Ravindra, N.G.; et al. The COVID-19 PHARMACOME: Rational selection of drug repurposing candidates from multimodal knowledge harmonization. bioRxiv 2020. [CrossRef]

58. Kouznetsova, J.; Sun, W.; Martínez-Romero, C.; Tawa, G.; Shinn, P.; Chen, C.Z.; Schimmer, A.; Sanderson, P.; McKew, J.C.; Zheng, W.; et al. Identification of 53 compounds that block ebola virus-like particle entry via a repurposing screen of approved drugs. Emerg. Microbes Infect. 2014, 3, e84. [CrossRef]

59. Xiao, X.; Wang, C.; Chang, D.; Wang, Y.; Dong, X.; Jiao, T.; Zhao, Z.; Ren, L.; dela Cruz, C.S.; Sharma, L.; et al. Identification of potent and safe antiviral therapeutic candidates against SARS-CoV-2. Front. Immunol. 2020, 11, 586572. [CrossRef]

60. Yoon, Y.S.; Jang, Y.; Hoenen, T.; Shin, H.; Lee, Y.; Kim, M. Antiviral activity of sertindole, raloxifene and ibutamoren against transcription and replication-competent ebola virus-like particles. BMB Rep. 2020, 53, 166-171. [CrossRef]

61. Dyall, J.; Coleman, C.M.; Hart, B.J.; Venkataraman, T.; Holbrook, M.R.; Kindrachuk, J.; Johnson, R.F.; Olinger, G.G.; Jahrling, P.B.; Laidlaw, M.; et al. Repurposing of clinically developed drugs for treatment of Middle East respiratory syndrome coronavirus infection. Antimicrob. Agents Chemother. 2014, 58, 4885-4893. [CrossRef]

62. Cham, L.B.; Friedrich, S.K.; Adomati, T.; Bhat, H.; Schiller, M.; Bergerhausen, M.; Hamdan, T.; Li, F.; Machlah, Y.M.; Ali, M.; et al. Tamoxifen protects from vesicular stomatitis virus infection. Pharmaceuticals 2019, 12, 142. [CrossRef]

63. Gaisina, I.N.; Peet, N.P.; Wong, L.; Schafer, A.M.; Cheng, H.; Anantpadma, M.; Davey, R.A.; Thatcher, G.R.J.; Rong, L. Discovery and structural optimization of 4-(aminomethyl)benzamides as potent entry inhibitors of ebola and marburg virus infections. $J$. Med. Chem. 2020, 63, 7211-7225. [CrossRef] [PubMed]

64. McMullan, L.K.; Flint, M.; Chakrabarti, A.; Guerrero, L.; Lo, M.K.; Porter, D.; Nichol, S.T.; Spiropoulou, C.F.; Albariño, C. Characterisation of infectious ebola virus from the ongoing outbreak to guide response activities in the Democratic Republic of the Congo: A phylogenetic and in vitro analysis. Lancet Infect. Dis. 2019, 19, 1023-1032. [CrossRef]

65. Zhou, Y.; Hou, Y.; Shen, J.; Huang, Y.; Martin, W.; Cheng, F. Network-based drug repurposing for novel coronavirus 2019NCoV/SARS-CoV-2. Cell Discov. 2020, 6, 14. [CrossRef] [PubMed]

66. Lubrano, V.; Balzan, S. Cardiovascular risk in COVID-19 infection. Am. J. Cardiovasc. Dis. 2020, 10, 284-293. [PubMed]

67. Johansen, L.M.; DeWald, L.E.; Shoemaker, C.J.; Hoffstrom, B.G.; Lear-Rooney, C.M.; Stossel, A.; Nelson, E.; Delos, S.E.; Simmons, J.A.; Grenier, J.M.; et al. A screen of approved drugs and molecular probes identifies therapeutics with anti-ebola virus activity. Sci. Transl. Med. 2015, 7. [CrossRef] [PubMed]

68. Aguilar-Pineda, J.A.; Albaghdadi, M.; Jiang, W.; Vera Lopez, K.J.; Davila, G.; Pharmd, D.-C.; Gómez Valdez, B.; Lindsay, M.E.; Malhotra, R.; Cardenas, C.L.L. Structural and functional analysis of female sex hormones against SARS-Cov2 cell entry. bioRxiv 2020. [CrossRef]

69. Wang, H.; Sun, X.; VonCannon, J.L.; Kon, N.D.; Ferrario, C.M.; Groban, L. Estrogen receptors are linked to angiotensin-converting enzyme 2 (ACE2), ADAM metallopeptidase domain 17 (ADAM-17), and transmembrane protease serine 2 (TMPRSS2) expression in the human atrium: Insights into COVID-19. Hypertens. Res. 2021, Feb 3, 1-3. [CrossRef]

70. Ghanbari, R.; Teimoori, A.; Sadeghi, A.; Mohamadkhani, A.; Rezasoltani, S.; Asadi, E.; Jouyban, A.; Sumner, S.C.J. Existing antiviral options against SARS-CoV-2 replication in COVID-19 patients. Future Microbiol. 2020, 15, 1747-1758. [CrossRef]

71. Mengist, H.M.; Mekonnen, D.; Mohammed, A.; Shi, R.; Jin, T. Potency, safety, and pharmacokinetic profiles of potential inhibitors targeting SARS-CoV-2 main protease. Front. Pharmacol. 2021, 11, 2495. [CrossRef]

72. Rajarshi, K.; Khan, R.; Singh, M.K.; Ranjan, T.; Ray, S.; Ray, S. Essential functional molecules associated with SARS-CoV-2 infection: Potential therapeutic targets for COVID-19. Gene 2021, 768, 145313. [CrossRef]

73. Nayeem, S.M.; Sohail, E.M.; Sudhir, G.P.; Reddy, M.S. Computational and theoretical exploration for clinical suitability of remdesivir drug to SARS-CoV-2. Eur. J. Pharmacol. 2021, 890. [CrossRef]

74. Cherrak, S.A.; Merzouk, H.; Mokhtari-Soulimane, N. Potential bioactive glycosylated flavonoids as SARS-CoV-2 main protease inhibitors: A molecular docking and simulation studies. PLoS ONE 2020, 15, e0240653. [CrossRef] 
75. Banerjee, R.; Perera, L.; Tillekeratne, L.M.V. Potential SARS-CoV-2 main protease inhibitors. Drug Discov. Today 2021, 26, 804-816. [CrossRef]

76. Mouffouk, C.; Mouffouk, S.; Mouffouk, S.; Hambaba, L.; Haba, H. Flavonols as potential antiviral drugs targeting SARS-CoV-2 proteases (3CLpro and PLpro), spike protein, RNA-dependent RNA polymerase (RdRp) and angiotensin-converting enzyme II receptor (ACE2). Eur. J. Pharmacol. 2021, 891. [CrossRef] [PubMed]

77. Chiou, W.C.; Hsu, M.S.; Chen, Y.T.; Yang, J.M.; Tsay, Y.G.; Huang, H.C.; Huang, C. Repurposing existing drugs: Identification of SARS-CoV-2 3C-like protease inhibitors. J. Enzym. Inhib. Med. Chem. 2021, 36, 147-153. [CrossRef]

78. Trott, O.; Olson, A.J. AutoDock Vina: Improving the speed and accuracy of docking with a new scoring function, efficient optimization, and multithreading. J. Comput. Chem. 2009, 31, 455-461. [CrossRef] [PubMed]

79. Giefing-Kröll, C.; Berger, P.; Lepperdinger, G.; Grubeck-Loebenstein, B. How sex and age affect immune responses, susceptibility to infections, and response to vaccination. Aging Cell 2015, 14, 309-321. [CrossRef] [PubMed]

80. Schock, H.; Zeleniuch-Jacquotte, A.; Lundin, E.; Grankvist, K.; Lakso, H.Å.; Idahl, A.; Lehtinen, M.; Surcel, H.M.; Fortner, R.T. Hormone concentrations throughout uncomplicated pregnancies: A longitudinal study. BMC Pregnancy Childbirth 2016, 16, 146. [CrossRef]

81. Kraus, T.A.; Engel, S.M.; Sperling, R.S.; Kellerman, L.; Lo, Y.; Wallenstein, S.; Escribese, M.M.; Garrido, J.L.; Singh, T.; Loubeau, M.; et al. Characterizing the pregnancy immune phenotype: Results of the viral immunity and pregnancy (VIP) study. J. Clin. Immunol. 2012, 32, 300-311. [CrossRef] [PubMed]

82. Rahimi, G.; Rahimi, B.; Panahi, M.; Abkhiz, S.; Saraygord-Afshari, N.; Milani, M.; Alizadeh, E. An overview of betacoronavirusesassociated severe respiratory syndromes, focusing on sex-type-specific immune responses. Int. Immunopharmacol. 2021, $92,107365$. [CrossRef]

83. Stanley, R.L.; Ohashi, T.; Gordon, J.; Nathan Mowa, C. A proteomic profile of postpartum cervical repair in mice. J. Mol. Endocrinol. 2018, 60, 17-28. [CrossRef] [PubMed]

84. Wu, H.J.; Oh, J.W.; Spandau, D.F.; Tholpady, S.; Diaz, J.; Schroeder, L.J.; Offutt, C.D.; Glick, A.B.; Plikus, M.V.; Koyama, S.; et al. Estrogen modulates mesenchyme-epidermis interactions in the adult nipple. Development 2017, 144, 1498-1509. [CrossRef] [PubMed]

85. Yang, F.; Li, N.; Gaman, M.A.; Wang, N. Raloxifene has favorable effects on the lipid profile in women explaining its beneficial effect on cardiovascular risk: A meta-analysis of randomized controlled trials. Pharmacol. Res. 2021, 166, 105512. [CrossRef] [PubMed]

86. Bunders, M.J.; Altfeld, M. Implications of sex differences in immunity for SARS-CoV-2 pathogenesis and design of therapeutic interventions. Immunity 2020, 53, 487-495. [CrossRef]

87. Hussman, J.P. Cellular and molecular pathways of COVID-19 and potential points of therapeutic intervention. Front. Pharmacol. 2020, 11, 1169. [CrossRef]

88. More, S.A.; Patil, A.S.; Sakle, N.S.; Mokale, S.N. Network analysis and molecular mapping for SARS-CoV-2 to reveal drug targets and repurposing of clinically developed drugs. Virology 2021, 555, 10-18. [CrossRef] [PubMed]

89. Sun, M.; Shankar, R.; Ko, M.; Chang, C.D.; Yeh, S.-J.; Li, S.; Liu, K.; Zhou, G.; Xing, J.; VanVelsen, A.; et al. Sex differences in viral entry protein expression, host responses to SARS-CoV-2, and in vitro responses to sex steroid hormone treatment in COVID-19. Res. Sq. 2020. [CrossRef]

90. The Human Protein Atlas. Available online: https://www.proteinatlas.org/ (accessed on 14 April 2021).

91. Cadegiani, F.A.; McCoy, J.; Gustavo Wambier, C.; Goren, A. Early antiandrogen therapy with dutasteride reduces viral shedding, inflammatory responses, and time-to-remission in males with COVID-19: A randomized, double-blind, placebo-controlled interventional trial (EAT-DUTA AndroCoV Trial—Biochemical). Cureus 2021, 13. [CrossRef]

92. Deng, Q.; ur Rasool, R.; Russell, R.M.; Natesan, R.; Asangani, I.A. Targeting androgen regulation of TMPRSS2 and ACE2 as a therapeutic strategy to combat COVID-19. iScience 2021, 24, 102254. [CrossRef]

93. Kotfis, K.; Lechowicz, K.; Drożdżal, S.; Niedźwiedzka-Rystwej, P.; Wojdacz, T.K.; Grywalska, E.; Biernawska, J.; Wiśniewska, M.; Parczewski, M. COVID-19-The potential beneficial therapeutic effects of spironolactone during SARS-CoV-2 infection. Pharmaceuticals 2021, 14, 71. [CrossRef]

94. Gennari, L.; Merlotti, D.; de Paola, V.; Martini, G.; Nuti, R. Bazedoxifene for the prevention of postmenopausal osteoporosis. Ther. Clin. Risk Manag. 2008, 4, 1229-1242. [CrossRef]

95. Fujiwara, S.; Hamaya, E.; Sato, M.; Graham-Clarke, P.; Flynn, J.A.; Burge, R. Systematic review of raloxifene in postmenopausal Japanese women with osteoporosis or low bone mass (osteopenia). Clin. Interv. Aging 2014, 9, 1879-1893.

96. Thilakasiri, P.; Huynh, J.; Poh, A.R.; Tan, C.W.; Nero, T.L.; Tran, K.; Parslow, A.C.; Afshar-Sterle, S.; Baloyan, D.; Hannan, N.J.; et al. Repurposing the selective estrogen receptor modulator bazedoxifene to suppress gastrointestinal cancer growth. EMBO Mol. Med. 2019, 11. [CrossRef] [PubMed]

97. Pozios, I.; Seel, N.N.; Hering, N.A.; Hartmann, L.; Liu, V.; Camaj, P.; Müller, M.H.; Lee, L.D.; Bruns, C.J.; Kreis, M.E.; et al. Raloxifene inhibits pancreatic adenocarcinoma growth by interfering with ER $\beta$ and IL-6/Gp130/STAT3 signaling. Cell. Oncol. 2021, 44, 167-177. [CrossRef] [PubMed]

98. Brábek, J.; Jakubek, M.; Vellieux, F.; Novotný, J.; Kolář, M.; Lacina, L.; Szabo, P.; Strnadová, K.; Rösel, D.; Dvořánková, B.; et al. Interleukin-6: Molecule in the intersection of cancer, ageing and COVID-19. Int. J. Mol. Sci. 2020, 21, 7937. [CrossRef] [PubMed] 
99. Smetana, K.; Smetana, K.; Brábek, J. Role of Interleukin-6 in Lung Complications in Patients with COVID-19: Therapeutic Implications. In Vivo 2020, 34, 1589-1592. [CrossRef] [PubMed]

100. Smetana, K.; Rosel, D.; Brábek, J. Raloxifene and bazedoxifene could be promising candidates for preventing the COVID-19 related cytokine storm, ARDS and mortality. In Vivo 2020, 34, 3027-3028. [CrossRef]

101. Borku Uysal, B.; Ikitimur, H.; Yavuzer, S.; Ikitimur, B.; Uysal, H.; Islamoglu, M.S.; Ozcan, E.; Aktepe, E.; Yavuzer, H.; Cengiz, M. Tocilizumab challenge: A series of cytokine storm therapy experiences in hospitalized COVID-19 pneumonia patients. J. Med. Virol. 2020, 92, 2648-2656. [CrossRef] [PubMed]

102. Salama, C.; Han, J.; Yau, L.; Reiss, W.G.; Kramer, B.; Neidhart, J.D.; Criner, G.J.; Kaplan-Lewis, E.; Baden, R.; Pandit, L.; et al. Tocilizumab in patients hospitalized with covid-19 pneumonia. N. Engl. J. Med. 2021, 384, 20-30. [CrossRef]

103. Van den Eynde, E.; Gasch, O.; Oliva, J.C.; Prieto, E.; Calzado, S.; Gomila, A.; Machado, M.L.; Falgueras, L.; Ortonobes, S.; Morón, A.; et al. Corticosteroids and tocilizumab reduce in-hospital mortality in severe COVID-19 pneumonia: A retrospective study in a Spanish hospital. Infect. Dis. 2021, 53, 291-302. [CrossRef] [PubMed]

104. Pettersen, E.F.; Goddard, T.D.; Huang, C.C.; Couch, G.S.; Greenblatt, D.M.; Meng, E.C.; Ferrin, T.E. UCSF Chimera-A visualization system for exploratory research and analysis. J. Comput. Chem. 2004, 25, 1605-1612. [CrossRef] [PubMed] 